\title{
Effect of Sulphur, Zinc, Boron and Iron on Growth and Yield of Wheat [Triticum aestivum $\mathrm{L}$.]
}

\author{
Sunil Kumar*, V.K. Verma, R.A. Yadav, R.N. Maurya, \\ Ranjit Kumar and Avinash Kumar Singh
}

Department of Agronomy, C.S. Azad University of Agriculture and Technology Kanpur (Uttar Pradesh), India

*Corresponding author

\begin{tabular}{|c|c|}
\hline & A B S T R A C T \\
\hline Keywords & \multirow{4}{*}{$\begin{array}{l}\text { The experiment conducted during Rabi season of } 2015-16 \text { at student instructional farm of } \\
\text { Chandra Shekhar Azad University of Agriculture and Technology, Kanpur to study the } \\
\text { Effect of sulphur, zinc, boron and iron on growth and yield of wheat }[\text { Triticum aestivum } \\
\text { L.] (Variety K-402). The experiment consist } 10 \text { treatments in randomized block design } \\
\text { viz., } \mathrm{T}_{1} \mathrm{NPK}(150: 60: 40 \mathrm{~kg} / \mathrm{ha}) \text { only, } \mathrm{T}_{2} \mathrm{NPK}+\text { Sulphur }(25 \mathrm{~kg} / \mathrm{ha}), \mathrm{T}_{3} \mathrm{NPK}+\mathrm{Zinc} \\
(5 \mathrm{~kg} / \mathrm{ha}), \mathrm{T}_{4} \mathrm{NPK}+\mathrm{B} \text { - Bon }(1.0 \mathrm{~kg} / \mathrm{ha}), \mathrm{T}_{5} \mathrm{NPK}+\text { Iron }(5 \mathrm{~kg} / \mathrm{ha}), \mathrm{T}_{6} \mathrm{NPK}+\mathrm{FYM}(10 \mathrm{t} / \mathrm{ha}) \text {, } \\
\mathrm{T}_{7} \mathrm{NPK}+\mathrm{Azotobacter}+\mathrm{PSB}, \mathrm{T}_{8} \mathrm{NPK}+\mathrm{FYM}+\text { Azotobacter }+\mathrm{PSB}, \mathrm{T}_{9} \mathrm{NPK}+\mathrm{S}+\mathrm{B}+ \\
\mathrm{Zn}+\mathrm{Fe}, \mathrm{T}_{10} \mathrm{NPK}+\mathrm{FYM}+\mathrm{S}+\mathrm{B}+\mathrm{Zn}+\mathrm{Fe} \text {. The treatment NPK }+\mathrm{FYM}+\mathrm{S}+\mathrm{Zn}+\mathrm{BO} \\
+\mathrm{Fe} \text { treatment found superior in terms of plant height, yield attributes and yield. The } \\
\text { maximum grain yield }(53.05 \mathrm{q} / \mathrm{ha} \text { a) recorded under NPK }+\mathrm{FYM}+\mathrm{S}+\mathrm{Zn}+\mathrm{Bo}+\mathrm{Fe} \text { and } \\
\text { maximum straw yield }(80.08 \mathrm{q} / \mathrm{ha}) \text { recorded under NPK }+\mathrm{FYM}+\text { Azoto }+\mathrm{PSB} \text { treatment } \\
\text { the increment in grain yield evaluated } 34.13 \% \text { compare to control treatment. }\end{array}$} \\
\hline $\begin{array}{l}\text { FYM, Azotobactor, } \\
\text { PSB, Zinc, Boron, } \\
\text { Iron, Yield }\end{array}$ & \\
\hline Article Info & \\
\hline $\begin{array}{l}\text { Accepted: } \\
20 \text { April } 2018 \\
\text { Available Online: } \\
\text { 10 May } 2018\end{array}$ & \\
\hline
\end{tabular}

\section{Introduction}

Wheat (Triticum aestivumL.) represents about $30 \%$ of the bread wheat is the major staple food source for a large part of global population. Globally wheat is grown in 122 countries and occupies an area of 215 million hectares producing nearly 753.23 million tonne of wheat during 2016.and estimated production of wheat in 2017 is 751.36 million metric tonnes. Could represent and increased of 16.13 million tonne in wheat production around the globe. Wheat is grown in india in an area of about 31 million hectare with production of 88.90 million tonne and normal productivity of $28.72 \mathrm{q} / \mathrm{ha}$. The crop is most successfully grown between latitude of $30^{\circ}$ to $60^{\circ} \mathrm{N}$ and $27^{0}$ to $40^{\circ} \mathrm{S}$ in the world, with a high altitude of $5000 \mathrm{~m}$. In India wheat is grown from $11^{0}, \mathrm{~N}$ to $30^{\circ} \mathrm{N}$ and from sea level up to an elevation of $3658 \mathrm{~m}$ in the Wheat grown all over India except Kerala state. Based on the agro-climatic conditions and varying agro ecological condition, India is broadly divided in to six wheat growing zones. The common bread wheat (Triticum aestivum 
L.) occupying more than 90 percent of the total wheat area along with 10 percent area under The major wheat producing states of India are Uttar Pradesh, Punjab, and Haryana with production 30.01, 16.47, and 11.63 million tonne respectively, first rank in Uttar Pradesh (32.26\%) second is Punjab (18.33\%) and third is Haryana $(13.50 \%)$ out of total wheat production but productivity is maximum in Punjab.

Indian soil are generally deficient in nutrients particularly nitrogen. It has been universally observed that nitrogen use efficiency which is low as about $30-37 \%$ is utilized while rest is lost through volatilization, denitrification and leaching. The phosphorus and potash use efficiency is $15-20 \%$ and $20-40 \%$ respectively while rest is fixed in the soil and not available to the plant easily.

The use of three major nutrient as chemical fertilizer is necessary to achieve production target of wheat. Micro nutrient are also necessary to achieve sustainability in production and to improve quality of wheat. Nitrogen is a major structural constituent of cell, it has been considered most important nutrient for all the development of plant life could hardly be conceivable without this element. Living organisms have a crucial role in controlling the transformation of plant nutrients is soil. In most soil N, P, and S are mainly present as various organic compounds that are unavailable for plant uptake. Understanding the role of micro organisms in regulating the conversion of these organic pools into plant available forms has received considerable attention from soil scientists and agronomist. Extracellular enzymes and organic compounds can be specifically exerted to solubilize plant available nutrients from soil organic matter, crop residues, or manures. Keeping these aspects in mind, the present study was conducted to evaluate the growth and yield of wheat.

\section{Materials and Methods}

The experiment was conducted in field number 6 at student instructional farm [SIF] of Chandra Shekhar Azad University of Agriculture and Technology, Kanpur (U.P.), India, during Rabi season 2015-16. Geographically the experimental site situated at an elevation of 125.9 meter above mean sea level, $26^{\circ} 20^{\prime \prime} 35^{\prime \prime}$ North latitude and $80^{\circ} 18^{\prime} 35^{\prime \prime}$ East longitude. It is situated in the alluvial belt of indogangetic plain in the central part of Uttar Pradesh, India that comes under agroclimatic zone-V.

The field was well leveled having good irrigation and drainage facilities. It has subtropical type of climate with hot summer and cold winter. During course of investigation since 26-11-2015 to 22-04-2016 the total rainfall received $49.9 \mathrm{~mm}$. in which $13.8 \mathrm{~mm}$ rainfall received under growth period $3^{\text {rd }}, 7^{\text {th }}, 8^{\text {th }}$ Standard meteorological week and $10.1 \mathrm{~mm}$ in $10^{\text {th }}, 11^{\text {th }}$ and $13^{\text {th }}$ Standard meteorological week emergence during flowering and milking stage.

The winter rain during 2015-16 quite low compared to previous winter season. The crop responded well to irrigation provided at critical growth stage. The average weekly maximum and minimum temperature during crop growth period range $41.3^{\circ} \mathrm{C}$ to $17.3^{\circ} \mathrm{C}$ and $24.1^{\circ} \mathrm{C}$ to $1.7^{\circ} \mathrm{C}$ respectively. The relative humidity range between $27 \%$ and $94 \%$, wind speed between 1.9 to $6.9 \mathrm{~km} \mathrm{hr}^{-1}$. The soil was silt loam in texture with $7.8 \mathrm{pH}$. The experiment consisted of 10 treatments viz. $\mathrm{T}_{1}$ NPK(150:60:40kg/ha) only, $T_{2}$ NPK+Sulphur (25.0kg/ha), $\quad \mathrm{T}_{3}$ NPK+Zinc $(5.0 \mathrm{~kg} / \mathrm{ha}), \mathrm{T}_{4}$ NPK+Boron $\quad(1.0 \mathrm{~kg} / \mathrm{ha}), \quad \mathrm{T}_{5} \quad \mathrm{NPK}+$ Iron (5.0kg/ha), T 6 NPK+FYM (10t/ha), $\mathrm{T}_{7} \mathrm{NPK}+$ Azotobacter+PSB,$\quad \mathrm{T}_{8} \quad \mathrm{NPK}+\mathrm{FYM}+$ Azotobacter $+\mathrm{PSB}, \mathrm{T}_{9} \mathrm{NPK}+\mathrm{S}+\mathrm{B}+\mathrm{Zn}+\mathrm{Fe}, \mathrm{T}_{10}$ $\mathrm{NPK}+\mathrm{FYM}+\mathrm{S}+\mathrm{B}+\mathrm{Zn}+\mathrm{Fe}$. The recommended dose of nitrogen, phosphorus and potassium @ 
$150 \mathrm{~kg}, 60 \mathrm{~kg}$ and $40 \mathrm{~kg} \mathrm{ha}{ }^{-1}$, respectively. Neem coated urea (46\%), DAP (18\% N, 46 $\left.\% \mathrm{P}_{2} \mathrm{O}_{5}\right)$, MOP $\left(60 \% \mathrm{~K}_{2} \mathrm{O}\right), \mathrm{FYM}(0.5 \% \mathrm{~N}$, $\left.0.25 \% \mathrm{P}_{2} \mathrm{O}_{5}, 0.5 \mathrm{~K}_{2} \mathrm{O}\right)$. The organic manures FYM and in combinations were applied uniformly as per treatment and incorporated into the soil before sowing. Full dose of phosphorus, potassium, sulphur, zinc, boron, iron and half dose of nitrogen were given just before sowing and remaining half dose of nitrogen as top dress after $1^{\text {st }}$ irrigation and $4^{\text {th }}$ irrigation through urea. The row to row spacing $20 \mathrm{~cm}$. and plant to plant spacing was $5 \mathrm{~cm}$. The data on various growth stages and seed yield were recorded indifferent treatments.

\section{Results and Discussion}

\section{Growth attribute}

The initial plant population and plant height under different treatments revealed under Table 1. The initial plant population and plant height at 45 DAS was not significantly affected by any of the treatments. Plant height at 90 DAS and at harvest stage was significantly influenced by different treatments.

Application of $\mathrm{NPK}+\mathrm{FYM}+\mathrm{S}+\mathrm{Zn}+\mathrm{B}+\mathrm{Fe}$ $\left(T_{10}\right)$ recorded highest plant height at all the growth stages and it was at par with NPK + $\mathrm{FYM}+$ Azoto $+\mathrm{PSB}\left(\mathrm{T}_{8}\right)$ and $\mathrm{NPK}+\mathrm{S}+\mathrm{Zn}$ $+\mathrm{Bo}+\mathrm{Fe}\left(\mathrm{T}_{9}\right)$ at $90 \mathrm{DAS}$ as well as $\mathrm{NPK}+\mathrm{S}$ $(25 \mathrm{Kg} / \mathrm{ha})\left(\mathrm{T}_{2}\right), \mathrm{NPK}+\mathrm{Zn}(5 \mathrm{Kg} / \mathrm{ha})\left(\mathrm{T}_{3}\right)$, $\mathrm{NPK}+\mathrm{Bo}(1 \mathrm{Kg} / \mathrm{ha})\left(\mathrm{T}_{4}\right), \mathrm{NPK}+\mathrm{Fe}(5$ $\mathrm{Kg} / \mathrm{ha})\left(\mathrm{T}_{5}\right), \mathrm{NPK}+\mathrm{FYM}$ (10 tonne/ha) $\left(\mathrm{T}_{6}\right)$, $\mathrm{NPK}+$ Azoto + PSB $\left(\mathrm{T}_{7}\right), \mathrm{NPK}+\mathrm{FYM}+$ Azoto $+\mathrm{PSB}\left(\mathrm{T}_{8}\right), \mathrm{NPK}+\mathrm{S}+\mathrm{Zn}+\mathrm{Bo}+$ $\mathrm{Fe}\left(\mathrm{T}_{9}\right)$ at harvest stage. Different micronutrient applied either individually or in combination with or without organic manure and microbial inoculants responded significant impact on increasing plant height of wheat crop. These results in line with the Kushare et al. 2009 nutrient levels and biofertilizers and Bindia and Mankotia 2005 also reported response of biofertilizer on wheat.

\section{Yield attribute and yield}

The yield attribute and yield are revealed in Table 2. The yield attributing character viz.length of ear, number of ear/plant and grain wt./ear recorded highest with $\mathrm{NPK}+\mathrm{FYM}+\mathrm{S}+\mathrm{Zn}+\mathrm{B}+\mathrm{Fe}\left(\mathrm{T}_{10}\right)$ and it was at par with $\mathrm{NPK}+\mathrm{FYM}+$ Azoto $+\mathrm{PSB}\left(\mathrm{T}_{8}\right)$ and $\mathrm{NPK}+\mathrm{S}+\mathrm{Zn}+\mathrm{Bo}+\mathrm{Fe}\left(\mathrm{T}_{9}\right)$ at $90 \mathrm{DAS}$ as well as NPK $+\mathrm{S}(25 \mathrm{Kg} / \mathrm{ha})\left(\mathrm{T}_{2}\right)$, NPK + $\mathrm{Zn}(5 \mathrm{Kg} / \mathrm{ha})\left(\mathrm{T}_{3}\right), \mathrm{NPK}+$ Bo $(1 \mathrm{Kg} / \mathrm{ha})\left(\mathrm{T}_{4}\right)$, $\mathrm{NPK}+\mathrm{Fe}(5 \mathrm{Kg} / \mathrm{ha})\left(\mathrm{T}_{5}\right), \mathrm{NPK}+\mathrm{FYM}(10$ tonne/ha) $\left(\mathrm{T}_{6}\right)$, NPK + Azoto + PSB $\left(\mathrm{T}_{7}\right)$, $\mathrm{NPK}+\mathrm{FYM}+$ Azoto + PSB $\left(\mathrm{T}_{8}\right), \mathrm{NPK}+\mathrm{S}+$ $\mathrm{Zn}+\mathrm{Bo}+\mathrm{Fe}\left(\mathrm{T}_{9}\right)$ similar finding also reported by Khan et al. (2013).

Number of grain/ear observed highest with $\mathrm{NPK}+\mathrm{FYM}+\mathrm{S}+\mathrm{Zn}+\mathrm{B}+\mathrm{Fe}\left(\mathrm{T}_{10}\right)$ and it was at par with $\mathrm{NPK}+\mathrm{FYM}+$ Azoto $+\operatorname{PSB}\left(\mathrm{T}_{8}\right)$, $\mathrm{NPK}+\mathrm{S}+\mathrm{Zn}+\mathrm{Bo}+\mathrm{Fe}\left(\mathrm{T}_{9}\right)$.

Biological yield and grain yield recorded highest with $\mathrm{NPK}+\mathrm{FYM}+\mathrm{S}+\mathrm{Zn}+\mathrm{B}+\mathrm{Fe}$ $\left(\mathrm{T}_{10}\right)$ which was at par with $\mathrm{NPK}+\mathrm{FYM}+$ Azoto $+\mathrm{PSB}\left(\mathrm{T}_{8}\right)$ and $\mathrm{NPK}+\mathrm{S}+\mathrm{Zn}+\mathrm{Bo}+$ $\mathrm{Fe}\left(\mathrm{T}_{9}\right)$ at 90 DAS as well as NPK + S (25 $\mathrm{Kg} / \mathrm{ha})\left(\mathrm{T}_{2}\right), \mathrm{NPK}+\mathrm{Zn}(5 \mathrm{Kg} / \mathrm{ha})\left(\mathrm{T}_{3}\right), \mathrm{NPK}+$ Bo (1 Kg/ha) $\left(\mathrm{T}_{4}\right), \mathrm{NPK}+\mathrm{Fe}(5 \mathrm{Kg} / \mathrm{ha})\left(\mathrm{T}_{5}\right)$, $\mathrm{NPK}+\mathrm{FYM}$ (10 tonne/ha) $\left(\mathrm{T}_{6}\right), \mathrm{NPK}+$ Azoto + PSB $\left(\mathrm{T}_{7}\right), \mathrm{NPK}+\mathrm{FYM}+$ Azoto $+\mathrm{PSB}\left(\mathrm{T}_{8}\right)$, $\mathrm{NPK}+\mathrm{S}+\mathrm{Zn}+\mathrm{Bo}+\mathrm{Fe}\left(\mathrm{T}_{9}\right)$ and significantly affected by different treatments.

The finding closely conformity with Mali et al(2015). The straw yield recorded maximum under NPK +FYM+ Azoto+PSB $\left(\mathrm{T}_{8}\right)$ which was at par with $\mathrm{NPK}+\mathrm{Zn}(5 \mathrm{Kg} / \mathrm{ha})\left(\mathrm{T}_{3}\right)$, NPK + Bo $(1 \mathrm{Kg} / \mathrm{ha})\left(\mathrm{T}_{4}\right), \mathrm{NPK}+\mathrm{Fe}(5 \mathrm{Kg} / \mathrm{ha})\left(\mathrm{T}_{5}\right)$, $\mathrm{NPK}+\mathrm{FYM}$ (10 tonne/ha) $\left(\mathrm{T}_{6}\right)$ and significantly superior over rest of the treatments. 
Table.1 Effect of different treatment on plant population and plant height of wheat

\begin{tabular}{|c|c|c|c|c|}
\hline Treatment & $\begin{array}{c}\text { Plant population } / \mathrm{m}^{2} \\
\text { (45 DAS) }\end{array}$ & $\begin{array}{l}\text { Plant height } \\
\text { (cm) (45 DAS) }\end{array}$ & $\begin{array}{l}\text { Plant height (cm) } \\
\text { (90 DAS) }\end{array}$ & $\begin{array}{c}\text { Plant height } \\
\text { (cm)(At harvesting) }\end{array}$ \\
\hline NPK (150:60:40) & 131.63 & 34.99 & 98.35 & 113.70 \\
\hline NPK + S (25 Kg/ha) & 136.67 & 35.10 & 98.60 & 114.24 \\
\hline NPK + Zn (5Kg/ha) & 138.127 & 35.77 & 99.82 & 114.37 \\
\hline NPK + Bo (1 Kg/ha) & 139.42 & 36.15 & 100.50 & 114.46 \\
\hline $\mathrm{NPK}+\mathrm{Fe}(5 \mathrm{Kg} / \mathrm{ha})$ & 132.13 & 36.27 & 100.80 & 114.79 \\
\hline NPK + FYM (10 tonne/ha) & 128.03 & 36.48 & 101.38 & 115.19 \\
\hline NPK + Azoto + PSB & 130.03 & 36.62 & 102.27 & 115.40 \\
\hline NPK + FYM + Azoto + PSB & 134.97 & 37.56 & 103.93 & 116.11 \\
\hline $\mathrm{NPK}+\mathrm{S}+\mathrm{Zn}+\mathrm{Bo}+\mathrm{Fe}$ & 135.96 & 37.87 & 105.89 & 116.32 \\
\hline $\mathrm{NPK}+\mathrm{FYM}+\mathrm{S}+\mathrm{Zn}+\mathrm{Bo}+\mathrm{Fe}$ & 138.40 & 40.06 & 106.06 & 117.81 \\
\hline $\mathrm{SE}(\mathrm{d}) \pm$ & 4.47 & 1.35 & 1.62 & 1.75 \\
\hline CD & N/A & 2.84 & 3.41 & 3.68 \\
\hline
\end{tabular}


Table.2 Effect of different treatment on yield attribute and yield of wheat

\begin{tabular}{|c|c|c|c|c|c|c|c|}
\hline Treatment & $\begin{array}{l}\text { Length of } \\
\text { ear }(\mathrm{cm})\end{array}$ & $\begin{array}{c}\text { No. of } \\
\text { ear/plant }\end{array}$ & $\begin{array}{l}\text { No. of grain } \\
\text { /ear }\end{array}$ & $\begin{array}{c}\text { Grain } \\
\text { weight/ } \\
\text { ear(g) }\end{array}$ & $\begin{array}{l}\text { Biological } \\
\text { yield } q / h a\end{array}$ & $\begin{array}{c}\text { Grain } \\
\text { yield } q / h\end{array}$ & $\begin{array}{c}\text { Straw } \\
\text { yield } \\
\text { (q/ha.) }\end{array}$ \\
\hline NPK(150:60:40kg/ha.) & 8.82 & 4.34 & 47.51 & 2.10 & 108.33 & 39.55 & 68.77 \\
\hline $\mathrm{NPK}+\mathrm{S}(25 \mathrm{Kg} / \mathrm{ha})$ & 8.90 & 4.52 & 48.49 & 2.06 & 115.27 & 42.30 & 72.97 \\
\hline $\mathrm{NPK}+\mathrm{Zn}(5 \mathrm{Kg} / \mathrm{ha})$ & 8.91 & 4.65 & 48.96 & 2.24 & 123.58 & 43.74 & 79.86 \\
\hline $\mathrm{NPK}+\mathrm{Bo}(1 \mathrm{Kg} / \mathrm{ha})$ & 9.01 & 4.80 & 49.17 & 2.29 & 124.90 & 45.83 & 79.16 \\
\hline NPK + Fe(5 Kg/ha) & 9.02 & 4.94 & 50.73 & 2.29 & 126.38 & 47.10 & 79.28 \\
\hline NPK + FYM(10 tonne/ha) & 9.14 & 5.00 & 51.67 & 2.42 & 124.27 & 47.80 & 76.47 \\
\hline NPK + Azoto+PSB & 9.15 & 5.27 & 51.96 & 2.49 & 114.88 & 41.88 & 73.00 \\
\hline NPK +FYM+ Azoto+PSB & 9.22 & 5.27 & 52.84 & 2.58 & 124.44 & 44.36 & 80.08 \\
\hline $\mathrm{NPK}+\mathrm{S}+\mathrm{Zn}+\mathrm{Bo}+\mathrm{Fe}$ & 9.32 & 5.35 & 52.95 & 2.62 & 127.78 & 51.49 & 76.28 \\
\hline $\mathrm{NPK}+\mathrm{FYM}+\mathrm{S}+\mathrm{Zn}+\mathrm{Bo}+\mathrm{Fe}$ & 9.69 & 5.83 & 54.94 & 2.78 & 129.16 & 53.05 & 76.11 \\
\hline $\operatorname{SE}(d) \pm$ & 0.40 & 0.56 & 1.12 & 0.32 & 2.66 & 1.02 & 1.79 \\
\hline CD & 0.84 & 1.18 & 2.71 & 0.68 & 5.60 & 2.13 & 3.77 \\
\hline
\end{tabular}




\section{References}

Abbas, G., Khan, M.Q., Khan, M.J., Hussain. F. and Hussain, I. (2009) Effect of iron on the growth and yield contributing parameters of wheat (Triticum aestivum L.) The Journal of Animal \& Plant Sciences, 19(3):

Bindia, B. D. and Mankotia, B. S, (2005) Effect of integrated nutrient management on growth and productivity of wheat crop. Agricultural Science Digest, 25(4): 235239.

Dahia, D. S. Dahia, S. S. Cathwal, O. P. Sharma, R. and Sheoran, R. S. (2008) Integrated nutrient management in wheat under ricewheat cropping system. Journal of Inter Academician, 4(1): 39-43

Fageria, N. K. (2002) Micronutrient influence on root growth of upland rice, common bean, corn, wheat, and soybean. Journal of Plant Nutrition 25(3): 613-622.

Faraji, H. Morodi, A. Jahanbin, S Rahimi, A. (2014) Studying the effect of nutrient fertilizers on agronomical and biological yield of wheat. Annals of Biological Research, 5(2): 26-29

Fisher,R.A and Yates (1947) Statistical analysis for biological agriculture and medical research. Pubished in Aliver and Boyd Edinburg, 23: 98-108

Habib, M (2009) Effect of foliar application of Zn and $\mathrm{Fe}$ on wheat yield and quality. African Journal of Biotechnology, Vol. 8 (24),

Harivna, L. Kotkova, B. Buresova, I. (2015) Effect of sulphur fertilization on yield and quality of wheat grain. Cereal research communication, 43(2): 344-352.

Kato, Y. and Yamagishi, J. (2011). Long-term effects of organic manure application on the productivity of winter wheat grown in a crop rotation with maize in Japan. Elsevier, vol. 120(3): 387-395.

Khan, M. A. Chattha, M. R. Awan, M. Z. Anjum, A. S. Imran, M. Kasana, M. I. (2013) Comparative efficiency of FYM and NPK on wheat. International Journal of Biology and Biotechnology, 10(4): 577-580.

Koutroubas, S.D., Antoniadis, V., Christos, A., Damalas, and Szderis., F.(2016). Effect of organic manure on wheat grain yield, nutrient.

Kumar, P. and Rana, D. S. (2012).Effect of integrated nutrient management on productivity and soil health in pegion pea and wheat cropping system. Indian Journal of Agronomy, 57(4): 333-337.

Kushare, B.M. Kushare, Y.M. and Sandhan, V.S.(2009) Effect of $\mathrm{N}$ and $\mathrm{P}$ levels and biofertilizers on the growth and yield of wheat under late sown irrigated conditions. International Journal of Agricultural Sciences, Vol. 5 Issue 2: 424-427.

Lakshminarayana, K., Narula, n. Hooda, I.S. and Faroda, A.S. (1992).Nitrogen economy in wheat (Triticum aestivum L.) through use of Azotobacter choroocossum. Indian Journal of Agricultural Sciences, 62 (1): 75-76.

Mali, D. V. Kharche, V. K. Jadhao, S. D. Katkar, R. N. Konde, N. M. Jadhao, S. M. Sonune, B. A.(2015) Effect of long term fertilization and manuring on soil quality and productivity under sorghum (Sorghum bicolor)-wheat (Triticum aestivum L.) sequence in inceptisol. Indian Journal of Agricultural Sciences, 85(5): 695-700.

Muhmood, A. Javed, S. Niaz, A. mazid, A. Mazid, T. (2014) Effect of boron on seed germination, seedling vigour and wheat yield. Journal of soil and environment, 33(11):7-22.

\section{How to cite this article:}

Sunil Kumar, V.K. Verma, R.A. Yadav, R.N. Maurya, Ranjit kumar and Avinash Kumar Singh. 2018. Effect of Sulphur, Zinc, Boron and Iron on Growth and Yield of Wheat [Triticum aestivum L.]. Int.J.Curr.Microbiol.App.Sci. 7(05): 2607-2612. doi: https://doi.org/10.20546/ijcmas.2018.705.301 